\title{
PENGARUH PERMAINAN LILIN PLASTISIN TERHADAP PENINGKATAN MOTORIK HALUS ANAK AUTISME USIA 6-12 TAHUN
}

\author{
Noor Indalestari ${ }^{1}$, Ari Damayanti Wahyuningrum ${ }^{2 *}$ Patemah $^{3}$ \\ ${ }^{1,2,3}$ STIKES Widyagama Husada Malang
}

*Corresponding author: Ari Damayanti Wahyunngrum STIKES Widyagama Husada Email: damayantiari1982@gmail,com

\begin{abstract}
The process of rapid growth occurs in childhood. This process of growth and development will be experienced by all children, including children with autism. Autism Spectrum Disorder (ASD) is a disorder in neurodevelopment, genetic and environmental factors play an important role so that it can lead to disturbances in communication, social interaction, and behavior patterns. The purpose of this study was to analyze the effect of plasticine wax therapy on improving fine motor skills in children with autism aged 6-12 years. This research method uses a pre-experimental design method using a one group pretest-posttest research design conducted on 16 respondents with autism aged 6 12 years. The data collection technique was carried out by providing a research instrument in the form of a Classroom Action Research (CAR) observation guide designed to measure the target ability in children with autism and then tested using SPSS with the Wilcoxon test type. The results of this study indicate that there is an effect of playing plasticine candles on the improvement of fine motor skills in children with autism $(p=0.000)$. Most of the 16 respondents who experienced fine motor disorders before being given the plasticine wax game were not good enough 10 people (62.5\%) and good enough 6 people $(37.5 \%)$ and fine motor disorders after being given the plasticine wax game quite good 10 people $(62.5 \%)$ and good 6 people $(37.5 \%)$. It can be concluded that there is an effect of playing plasticine candles on the improvement of fine motor skills of children with autism aged 6 12 years at UPT Special Needs Services Malang City.
\end{abstract}

Keywords: Plasticine Candle Game; Autism; Fine Motor

\section{Abstrak}

Proses terjadinya pertumbuhan yang pesat terjadi pada masa kanak-kanak. Proses pertumbuhan dan perkembangan ini akan dialami oleh semua anak tidak terkecuali pada anak autisme. Autisme Spectrum Disorder (ASD) adalah gangguan pada perkembangan saraf, faktor genetik dan lingkungan sangat berperan penting sehingga dapat memunculkan gangguan pada komunikasi, interaksi sosial, dan pola perilaku. Tujuan dari penelitian ini adalah untuk menganalisis pengarut terapi lilin plastisin terhadap peningkatan motorik halus pada anak dengan autisme usia 6-12 tahun Metode penelitian ini menggunakan metode pra eksperimental design menggunakan desian penelitian one group pretestposttest yang dilakukan pada 16 responden penderita autisme usia 6-12 tahun.di UPT Layanan Pendidikan Anak Berkebutuhan Khusus Kota Malang. Teknik pengumpulan data dilakukan dengan cara memberikan instrument penelitian berupa pedoman observasi Classroom Action Research (CAR) yang dirancang untuk mengukur target kemampuan pada anak autisme kemudian di uji menggunakan SPSS dengan jenis uji wilcoxon Hasil penelitian ini menunjukkan terdapat pengaruh permainan lilin plastisin terhadap peningkatan motorik halus anak autisme $(\mathrm{p}=0,000)$. Dari 16 responden terbanyak yang mengalami gangguan motorik halus sebelum diberikan permainan lilin plastisin kurang baik 10 orang $(62.5 \%)$ dan cukup baik 6 orang $(37.5 \%)$ dan gangguan motorik halus setelah diberikan permainan lilin plastisin cukup baik 10 orang $(62.5 \%)$ dan baik 6 orang (37.5\%). Dapat disimpulkan bahwa terdapat pengaruh permainan lilin plastisin terhadap peningkatan motorik halus anak autisme usia 6-12 tahun di UPT Layanan Berkebutuhan Khusus Kota Malang.

Kata Kunci: Permainan Lilin Plastisin;Autisme: Motorik Halus 


\section{PENDAHULUAN}

Proses terjadinya pertumbuhan yang pesat terjadi pada masa kanak-kanak. Proses pertumbuhan dan perkembangan ini akan dialami oleh semua anak tidak terkecuali pada anak autisme. Autisme Spectrum Disorder (ASD) adalah gangguan pada perkembangan saraf, faktor genetik dan lingkungan sangat berperan penting sehingga dapat memunculkan gangguan pada komunikasi, interaksi sosial, dan pola perilaku. Penderita autisme ini cenderung lebih asik pada dunianya sendiri. (Daniel et al., 2019)

\section{Survey data dari California Departement of}

Developmental Service. Amerika Serikat (AS) melaporkan bahwa terjadinya peningkatan anak penyandang autisme sebesar 31\%. Ikatan Dokter Anak AS dan Pusat Kontrol dan Pencegahan Penyakit AS menambahkan bahwa jumlah autis mencapai 1:116 anak. Dimana 10 tahun sebelumnya perbandingan hanya 1:2500 anak. (Wawan \& Anna, 2016) Hasil prediksi dari WHO terdapat 1 dari 160 anak didunia menderita gangguan spektrume autisme. Sedangkan di Indonesia terdapat 2 kasus baru per-1000 penduduk, jumlah penduduk Indonesia 237,5 juta dengan laju pertumbuhan 1.14\%. maka perkiraan ASD di Indonesia yaitu 2,4 juta orang dengan pertambahan 500orang/tahun penyandang autisme.

Penderita autisme sangat memperihatinkan karena banyak orang tua yang tidak mengetahui cara untuk mengembangkan kemampuan motorik halus pada anak autisme, apabila cara tersebut dapat diterapkan oleh orang tua maka anak dapat bersikap dan berkembang seperti anak pada umumnya dan tidak dibeda-bedakan dengan anak tanpa menyandang autisme. Setiap anak perlu mendapatkan bantuan secara rutin dan terus menerus agar motorik halus anak dapat berkembang ( $\mathrm{T}$ \& Matulessy, 2015)

Pentingnya mengurangi gangguan ini pada anak karena anak dengan autis bisa menyebabkan anak tersebut tidak halus anak perlu berkembang agar dapat meningkatkan kemampuan mandiri seperti aktivitas bantu diri. Apabila keterampilan motorik halus tidak dapat berkembang maka aktivitas pada anak juga dapat terganggu (Prasetyanti \& Aminah, 2017).

Perlakuan yang dapat diberikan kepada anak penderita autisme salah satunya dengan bermain. Beberapa survey literatur telah menggunakan perlakuan terapi bermain (Prasetyanti \& Aminah, 2017). Permainan dapat membantu anak untuk mengembangkan kemampuannya karena pada saat anak bermain anak tersebut merasakan adanya kebebasan tanpa ada suatu kekangan.

Penggunaan terapi bermain lilin plastisin pada anak ini tergolong murah dan mampu meningkatkan fungsi motorik halus pada anak karena anak akan mampu belajar meremas, memegang, menjepit, mencampur. Dan peermainan juga dapat menarik perhatian dari anak autis, anak autis cenderung suka terhadap benda benda berwarna. Perlu diperhatikan juga untuk menerapkan terapi bermain pada anak juga butuh pengawasan agar permainan yang diberikan termasuk dalam permainan yang aman bagi anak tersebut. (Prasetyanti \& Aminah, 2017)

Hasil penelitian sebelumnya penelitian terapi bermain lilin plastisin ini memiliki efek terhadap motorik halus anak. Namun didaerah malang pengembangan motorik halus pada anak autis sangat jarang dilakukan sehingga anak cenderung menutup diri. Sehingga anakanak yang memiliki autis tersebut tidak dapat meneruskan kejenjang berikutnya yaitu kejenjang sekolah umum (Rossyana Septyasih, 2014).

Hasil penelitian menunjukkan bahwa motorik halus anak dengan penderita autis dapat berkembang setelah diberikan terapi bermain lilin plastisin karena umumnya anak-anak mudah tertarik dengan permainan. Namun terapi ini harus dilakukan dengan tingkat 
kesabaran karena anak autisme mudah hilang fokus (Pangestika \& Setiyorini, 2015). Penelitian dengan judul ini menarik untuk diteliti karena didaerah malang pengembangan motorik halus masih sangat jarang dikembangkan (Rossyana Septyasih, 2014)

\section{METODE}

Desain Penelitian ini adalah pra eksperimental design menggunakan desian penelitian one group pretestposttest. Dimana desain penelitian ini cukup tepat dilakukan peneliti dengan sengaja memberi intervensi (perlakuan) kepada subjek. Pengamatan dilakukan terhadap efek perlakuan. Perbedaan hasil pengamatan sebelum dan sesudah atau antar kelompok dianggap sebagai efek perlakuan. Setalah didapatkan data pre dan post-test tersebut lalu dilakukan perbandingan dari kedua data tersebut. Dimana telah didapatkan data dengan adanya peningkatan motorik halus setelah diberikannya pendekatan bermain. (Septyasih et al., 2014) Teknik sampling nonprobabilitas adalah teknik pengambilan sample dari populasi yang ditemukan atau ditentukan sendiri oleh peneliti atau menurut pertimbangan. Penarikan sampel dari populasi secara purposive adalah cara penarikan sample yang dilakukan dengan memilih subjek berdasarkan kriteria spesifik yang ditetapkan oleh peneliti. Dalam penelitian ini pengambilan sampel menggunakan teknik purposive sampling dipakai apabila peneliti hanya memiliki satu kelompok populasi, sehingga tidak ada pertimbangan untuk memilih sampel lain. Penelitian dilakukan selama bulan Juni sampai dengan bulan Juli, penelitian dilakukan dalam masa pandemic virus covid-19 maka penelitian dilakukan secara online melalui WhatsApp untuk memutus penyebaran virus covid-19. Variabel dalam penelitian ini adalah terapi permainan lilin plastisin dan motorik halus pada anak usia 6-12 tahun dengan autisme. Teknik pengumpulan data dilakukan dengan cara memberikan instrument penelitian berupa Instrumen yang digunakan oleh peneliti dalam penelitian ini adalah alat berupa pedoman observasi Classroom Action Research (CAR) yang dirancang untuk mengukur target kemampuan pada anak autisme. Analisa data yang digunakan adalah univariat dan bivariat dengan analisa bivariat menggunakan uji wilxocon

\section{HASIL DAN PEMBAHASAN}

Responden penelitian merupakan siswa dari UPT Layanan Berkebutuhan Khusus Kota Malang yang mengalami gangguan motorik halus pada anak autisme usia 6-12 Tahun.

Tabel 1. Karakteristik Responden Variabel Frekuensi Presentase

(n) $\quad(\%)$

\begin{tabular}{lcc}
\hline Jenis & & \\
Kelamin & 4 & 25.0 \\
Perempuan & 12 & 75.0 \\
Laki-Laki & & \\
Usia & 0 & 0.0 \\
6 Tahun & 5 & 31.3 \\
7 Tahun & 3 & 18.8 \\
8 Tahun & 3 & 18.8 \\
9 Tahun & 2 & 12.5 \\
10 Tahun & 2 & 12.5 \\
11 Tahun & 1 & 6.3 \\
12 Tahun & & \\
Kedudukan & 10 & 62.5 \\
Anak & 6 & 37.5 \\
Anak & & \\
Pertama & & \\
Anak Kedua & & \\
\hline
\end{tabular}

Sumber : (Data Penelitian, 2021)

Tabel 1. menjelaskan bahwa responden terbanyak dari karakteristik jenis Responden terbanyak yang mengalami gangguan motorik halus berdasarkan karakteristik jenis kelamin yaitu laki-laki sejumlah 12 (75\%), karakteristik usia yaitu 7 tahun sebanyak 5 (31.3\%), karakteristik kedudukan anak terbanyak anak pertama $10(62.5 \%)$.

Faktor yang mempengaruhi perkembangan motorik halus salah satunya yaitu usia. Hal ini disebabkan karena semakin bertambahnya usia maka 
kemampuan anak juga meningkat sesuai dengan usianya namun menurut (Purbalingga, 2012) pertumbuhan dan perkembangan anak sangat dipengaruhi oleh stimulusstimulus yang diberikan oleh lingkungan sekitar. Apabila stimulus-stimulus tersebut berjalan atau dijalankan dengan baik, maka sangat mungkin hal tersebut dapat menjadikan anak memiliki kemampuan kognitif, motorik, dan bahasa yang berkembang sangat baik pula. Akan tetapi, ada juga anak yang memang memiliki permasalahan dalam tumbuh kembang karena anak tersebut mengalami gangguan fisik. Salah satu gangguan perkembangan yang sering dikeluhkan oleh para orangtua serta kerap ditemui di sekitar kita ialah autisme. Autisme merupakan suatu kumpulan sindrom yang mengganggu saraf. Penyakit ini mengganggu perkembangan anak, diagnosisnya diketahui dari gejalagejala yang tampak dan ditunjukan dengan adanya penyimpangan perkembangan.

\section{Tabel 2. Pretest Motorik Halus Anak Autisme} Pretest Frekuensi Presentase

(n)

(\%)

\begin{tabular}{lcc}
\hline Kurang & 10 & 62.5 \\
baik & 6 & 37.5 \\
Cukup & 0 & 0.0 \\
baik & 16 & 100.0 \\
Baik & & \\
total & & \\
\hline
\end{tabular}

Sumber : (Data Penelitian, 2021)

Tabel 2. menjelaskan bahwa sebelum dilakukan permainan pengukuran kemampuan motorik halus diukur dengan menggunakan pedoman observasi Classroom Action Research (CAR) berdasarkan hasil penilaian kemampuan motorik halus terdapat $10(62.5 \%)$ responden kurang mampu.

Menurut (Di \& Autisme, n.d.) perkembangan motorik merupakan salah satu faktor yang terpenting dalam perkembangan individu yang mempengaruhi perkembangan selanjutnya. Permasalahan yang mungkin terjadi apabila kemampuan motorik halus anak kurang dilatih dikhawatirkan anak akan kurang mampu mengfungsikan otot-otot kecil dalam menggerakan jari dan kedua tanganya, anak kurang mampu mengkoordinasikan kecepatan tangan. Melihat dampak negatif dari kurangnya stimulus motorik halus, maka dari itu penting untuk meningkatkan kemampuan motorik halus anak sejak dini. Motorik halus merupakan kemampuan yang menggunakan jari jemari, tangan dan gerakan pergelangan tangan dengan tepat. Penguasaan motorik halus sama pentingnya dengan penguaaan motorik kasar. Motorik halus adalah gerakan yang dilakukan dengan menggunakan otot halus.

Hasil penelitian sejalan dengan penelitian judul Efektivitas Plastisin Untuk Meningkatkan Motorik Halus didapatkan hasil kondisi baseline awal adalah kemampuan awal anak dalam melakukan keterampilan motorik halus sebelum diberikan intervensi pengamatan pertama dengan skor $10 \%$, pada pengamatan kedua dan ketiga memperoleh $20 \%$, pengamatan keempat dan kelima anak memperoleh skor $30 \%$. Terdapat skor paling tinggi pada baseline pertama pada anak adalah $30 \%$ kemudian kondisi intervensi terlihat stabil pada skor $80 \%$ dan pada skor yang diperoleh pada baseline kedua terlihat stabil yaitu $80 \%$ hal ini membuktikan bahwa dari 10 item tes perbuatan anak mampu melakukan 8 dari 10 item keterampilan motorik halus.

Bermain lilin plastisin tidak diterapkan dalam kehidupan sehari-hari oleh keluarga karena keluarga menghindari lilin plastisin termakan oleh anak apabila tidak dipantau secara langsung oleh keluarga. Proses terapi dalam penelitian berlangsung dalam situasi pandemi Covid-19, responden bermain dengan keluarga sehingga keluarga juga mengetahui proses yang dijalani oleh peneliti. 
Tabel 3. Posttest Motorik Halus Anak Autisme

Indalestari, Noor. dkk. (2021).

\begin{tabular}{lcc}
\hline Posttest & $\begin{array}{c}\text { Frekuensi } \\
(\mathbf{n})\end{array}$ & $\begin{array}{c}\text { Presentase } \\
(\%)\end{array}$ \\
\hline Kurang & 0 & 0.0 \\
baik & 10 & 62.5 \\
Cukup & 6 & 37.5 \\
baik & 16 & 100.0 \\
Baik & & \\
Total & & \\
\hline
\end{tabular}

Sumber : (Data Penelitian, 2021)

Tabel 3. menjelaskan bahwa responden penelitian memiliki kemampuan motorik halus sesudah diberikan permainan lilin plastisin yang berbeda dengan mayoritas kemampuan motorik halus meningkat menjadi cukup mampu $10(62.5 \%)$ dan mampu $6(37.5 \%)$ responden.

Berdasarkan hasil penelitian perbedaan peningkatan skor posttest dari setiap responden terjadi karena setiap individu memiliki respon yang berbeda terhadap terapi, hal tersebut dapat mempengaruhi skor yang diperoleh terapi melalui perubahan motorik halus.

Hasil penelitian sesuai dengan (Nadirah \& Raudhoh, 2019) didapatkan hasil sebelum dilakukan intervensi skor post test sebesar 416, terjadinya peningkatan skor sesudah pemberian intervensi sebesar 19.28\%. Data analisa menggunakan uji parametrik yaitu paired sample T-test didapatkan niai $\mathrm{p}-\mathrm{V}=0.008$ sehingga dapat disimpulkan terdapat pengaruh identifikasi warna primer pada anak autisme.

Kemampuan motorik halus yang belum optimal sangat mempengaruhi kemampuan akademik maupun kemampuan untuk melakukan aktivitas bantu diri, hal tersebut ditunjukan dengan anak yang belum mampu untuk menulis dan belum luwes dalam melakukan aktivitas bantu diri seperti berpakaian, makan, dan menyikat gigi. Media tersebut dipilih berdasarkan dengan pendapat ahli yang berpendapat bahwa dengan lilin plastisin memungkinkan anak untuk melakukan berbagai kegiatan motorik halus dan melalui pengalaman latihan yang berkelanjutan dengan menggunakan lilin plastisin, kemampuan motorik halus anak terstimulasi untuk berkembang (Purbalingga, 2012)

Tabel 4. Hasil Uji Wilcoxon.

\begin{tabular}{|c|c|c|c|c|c|c|}
\hline \multirow{2}{*}{$\begin{array}{c}\text { Peng } \\
\text { ukur } \\
\text { an }\end{array}$} & \multirow{2}{*}{$\begin{array}{l}\text { Keter } \\
\text { angan }\end{array}$} & \multicolumn{2}{|c|}{ Pretest } & \multicolumn{2}{|c|}{ Posttest } & \multirow{2}{*}{$\begin{array}{c}\text { Nilai } \\
p\end{array}$} \\
\hline & & $\mathbf{n}$ & $\%$ & $\mathbf{n}$ & $\%$ & \\
\hline \multirow{3}{*}{$\begin{array}{l}\text { Moto } \\
\text { rik } \\
\text { halus }\end{array}$} & $\begin{array}{l}\text { Kuran } \\
\text { g baik }\end{array}$ & 10 & $\begin{array}{c}62 . \\
5\end{array}$ & 0 & 0.0 & \multirow{3}{*}{$\begin{array}{l}0.00 \\
0 \\
(<0,0 \\
5)\end{array}$} \\
\hline & $\begin{array}{l}\text { Cukup } \\
\text { baik }\end{array}$ & 6 & $\begin{array}{c}37 . \\
5\end{array}$ & 10 & 62.5 & \\
\hline & Baik & 0 & 0 & 6 & 37.5 & \\
\hline Total & & 16 & $\begin{array}{c}100 \\
.0\end{array}$ & 16 & $\begin{array}{c}100 . \\
0\end{array}$ & \\
\hline
\end{tabular}

Sumber : (Data Penelitian, 2021)

Tabel 4. menggambarkan pengaruh permainan lilin plastisin terhadap kemampuan motorik halus anak autisme didapat hasil pretest dan posttest. Hasil analisa data menggunakan uji wilxocon untuk menguji adanya pengaruh permainan lilin plastisin terhadap peningkatan motorik halus pada anak autisme didapatkan hasil signifikan $0.000(\mathrm{p}<0,05)$, maka dapat disimpulkan bahwa permainan lilin plastisin terhadap peningkatan motorik halus anak autis memiliki pengaruh yang signifikan. Setelah dilakukan penelitian permainan lilin plastisin pada anak autisme untuk meningkatkan motorik halus didapatkan hasil seperti yang tertera pada tabel 5.8 dengan hasil uji wilcoxon didapat nilai Mean pada pretest yaitu 29.6875 Dan posttest yaitu 35.6250 dengan nilai signifikan 0.000 menunjukan bahwa $p$ value kurang dari 0,05 sehingga sesuai dengan hipotesis penelitian jika $p$ value kurang dari 0,05 maka Hipotesis diterima yang berarti ada pengaruh permainan lilin plastisin terhadap peningkatan motorik halus anak autisme usia 6-12 tahun di UPT Layanan Pendidikan Anak Berkebutuhan Khusus Kota Malang. Penelitian ini didukung oleh penelitian sebelumnya (Prasetyanti \& Aminah, 2017) didapatkan hasil uji Wilcoxon dengan nilai $\mathrm{p}-\mathrm{V}=0.025$ sehingga $p$ $V<0.05$ maka H0 ditolak dan H1 diterima artinya ada pengaruh stimulasi menggunakan terapi permainan lilin 
Indalestari, Noor. dkek. (2021).

plastisin terhadap peningkatan motorik halus.

Berdasarkan hasil evaluasi penelitian didapatkan bahwa terdapat peningkatan motorik halus pada anak, namun karena pandemi kegiatan ini hanya dapat dipantau secara online.

\section{KESIMPULAN}

Berdasarkan hasil penelitian mengenai pengaruh permainan lilin plastisin terhadap peningkatan motorik halus pada anak autisme usia 6-12 tahun di UPT Layanan Berkebutuhan Khusus Kota Malang dapat disimpulkan: Hasil analisa data kemampuan motorik halus sebelum diberikan permainan lilin plastisin adalah kurang mampu dengan jumlah responden 10 (62.5\%) dan cukup mampu $6(37.5 \%)$ responden. Hasil analisa data kemampuan motorik halus sesudah diberikan permainan lilin plastisin adalah cukup mampu dengan jumlah responden 10 (62.5\%) dan mampu 6 (37.5\%) responden. Hasil analisa pengaruh permainan lilin plastisin terhadap peningkatan motorik halus terhadap anak autisme usia 6-12 tahun di UPT Layanan Pendidikan Khusus Kota Malang dengan menggunakan uji wilcoxon didapatkan nilai signifikan 0.000 yang berarti $p$ value kurang dari 0,05 sehingga dapat disimpulkan bahwa terdapat pengaruh permainan lilin plastisin terhadap peningkatan motorik halus anak autisme usia 6-12 tahun di UPT Layanan Berkebutuhan Khusus Kota Malang.

\section{UCAPAN TERIMA KASIH}

Terima kasih kepada UPT Layanan Pendidikan Anak Berkebutuhan Khusus Kota Malang yang telah memberi ijin untuk melakukan penelitian pengaruh permainan lilin plastisin terhadap anak autisme usia 6-12 tahun.

\section{DAFTAR RUJUKAN}

Daniel, V., Vera, G., López, C. Q., Católica, U., Amigó, L., \& Medellín, T. (2019). Structural Equation Model for Studying the Autism Spectrum Disorder. August.

https://doi.org/10.5829/idosi.mejsr.2019.114.118

Di, A., \& Autisme, S. L. B. (n.d.). Jurnal Abdimas Saintika. 1.

Fransisca Anggraeni Suriantoso, Ni Made Ayu Suryaningsih, C. E. P. (2016). Meningkatkan kemampuan motorik halus melalui permainan playdough pada anak kelompok bermain di paud tegaljaya. Pendidikan Universitas Dhyana Pura, 1(1).

Hasyim et al. (2018). Jurnal psikologi. Jurnal Psikologi, 43(3), $248-263$.

https://journal.ugm.ac.id/jpsi/article/view/17801/1 5824

Hillus, J., Moseley, R., Roepke, S., \& Mohr, B. (2019). Action Semantic Deficits and Impaired Motor Skills in Autistic Adults Without Intellectual Impairment. Frontiers in Human Neuroscience, 13(July), 1-12.

https://doi.org/10.3389/fnhum.2019.00256

Ismet, I. (2019). Intervensi Anak Usia Dini Penyandang Autis. Journal of Early Childhood Care and Education, 2(1), 30.

https://doi.org/10.26555/jecce.v2i1.176

Istiqomah, H., \& Suyadi, S. (2019). Perkembangan Fisik Motorik Anak Usia Sekolah Dasar Dalam Proses Pembelajaran (Studi Kasus Di Sd Muhammadiyah Karangbendo Yogyakarta). El Midad, 11(2), 155168. https://doi.org/10.20414/elmidad.v11i2.1900

Kartini, K., \& Sujarwo, S. (2014). Penggunaan Media Pembelajaran Plastisin Untuk Meningkatkan Kreativitas Anak Usia. Jurnal Pendidikan Dan Pemberdayaan Masyarakat, 1(2), 199. https://doi.org/10.21831/jppm.v1i2.2689 
Nadirah, R., \& Raudhoh, S. (2019). Jurnal Psikologi Jambi Kemampuan Identifikasi Warna Primer Pada Anak Autis Di Tk Khusus Harapan Mulia Kota Jambi Effectivity Of Playdough Game To Upgrade The Ability Of Primary Color Identification In Autistic Children In Inclusion Rizqiyah Nadira , , Sit. 4(1), 1-9.

Ningrum. (2017). Pengaruh Penggunaan Metode Berbasis Pemecahan Masalah (Problem Solving) Terhadap Hasil Belajar Ekonomi Siswa Kelas X Semester Genap Man 1 Metro Tahun Pelajaran 2016/2017. Pengaruh Penggunaan Metode Berbasis Pemecahan Masalah (Problem Solving) Terhadap Hasil Belajar Ekonomi Siswa Kelas X Semester Genap Man 1 Metro Tahun Pelajaran 2016/2017, 5(1), 145-151.

Øien, R. A., Candpsych, S. S., Volkmar, F. R., Shic, F., Cicchetti, D. V., Nordahl-Hansen, A., Stenberg, N., Hornig, M., Havdahl, A., Øyen, A. S., Ventola, P., Susser, E. S., Eisemann, M. R., \& Chawarska, K. (2018). Clinical features of children with autism who passed 18-month screening. Pediatrics, 141(6). https://doi.org/10.1542/peds.2017-3596

Pangestika, R. A., \& Setiyorini, E. (2015). The effect of Plasticine play to fine motor development at pre school children. Jurnal Ners Dan Kebidanan (Journal of Ners and Midwifery), 2(2), 169-175. https://doi.org/10.26699/jnk.v2i2.art.p169-175

Prasetyanti, D. K., \& Aminah, S. (2017). Pengaruh Permainan Lilin Plastisin Terhadap the Influence of Wax Plasticine Play Therapy for the Development of Fine Motor Skills in Preschool. Jurnal Penelitian Keperawatan, 3(2), 124-130.

Purbalingga, K. (2012). Studi Deskriptif Terapi Terhadap Penderita Autisme Pada Anak Usia Dini Di Mutia Center Kecamatan Bojong Kabupaten Purbalingga. Indonesian Journal of Early Childhood Education Studies, 1(1), 44-48
. https://doi.org/10.15294/ijeces.v1i1.9204

Raharjo, D., Alfiyanti, D., \& Purnomo, S. E. (2014). Pengaruh terapi bermain menggunting terhadap peningkatan motorik halus pada anak autisme usia 11-15 tahun Di Sekolah Luar Biasa Negeri Semarang. Jurnal Ilmu Keperawatan Dan Kebidanan (JIKK), 2(1), 1-9

. https://doi.org/10.1134/S0012501609090061

Sari, I., \& Rakimahwati, R. (2019). Peningkatan kemampuan motorik halus melalui bermain playdough di taman kanak-kanak qur'aniah air runding pasaman barat. JRTI (Jurnal Riset Tindakan Indonesia), 4(1), 37. https://doi.org/10.29210/3003279000

Septia, D., \& Mauliani, L. (2016). Pengaruh Perilaku Anak Berkebutuhan Khusus Terhadap Desain Fasilitas Pendidikan Studi Kasus: Bangunan Pendidikan Anak Autis

. Jurnal.Umj.Ac.Id/Index.Php/Semnastek P-, 2(November), 1.

Septyasih, R., Prastiwi, S., \& Setyono, D. (2014). Pengaruh Pendekatan Bermain Terhadap

Kemampuan Interaksi Sosial Anak Autis. Jurnal Keperawatan, 5, 39-47.

https://doi.org/10.22219/JK.V5I1.1859

Suhartanti, I., Rufaida, Z., Setyowati, W., \& Ariyanti, F. W. (2019). Effectiveness of Colouring and Playdough Method on Fine Motoric Skills of Pre School Student in Mojokerto, Indonesia. International Journal of Innovative Research and Development, 8(10), 242-251. https://doi.org/10.24940/ijird/2019/v8/i10/oct1907 4

Sunaryati, T., \& Arfa, M. (2018). Studi Eksperimen Pelatihan Advanced Search Pada Portal Jurnal Emerald Insight Bagi Kemampuan Penelusuran Informasi Mahasiswa Program Studi S-1 Ilmu Perpustakaan Angkatan 2017 Fakultas Ilmu 
Budaya Universitas Diponegoro. Jurnal Ilmu

Perpustakaan, 7(2), 41-50.

https://ejournal3.undip.ac.id/index.php/jip/article/v

iew/22897

T, D. R., \& Matulessy, A. (2015). Pengaruh Terapi Bermain FlashcardUntuk Meningkatkan Interaksi Sosial Pada Anak Autis di Miracle Centre Surabaya. Persona:Jurnal Psikologi Indonesia, $4(1)$.

\section{https://doi.org/10.30996/persona.v4i1.490}

Wawan, W., \& Anna, A. (2016). Keefektifan Strategi Visual dalam Pembelajaran Keterampilan Sosial pada Anak dengan Kondisi Spektrum Autis Tipe Sindroma Asperger (ASD). Jurnal Kesehatan, 7(1), 119. https://doi.org/10.26630/jk.v7i1.128

Weston, C. S. E. (2019). Four social brain regions, their dysfunctions, and sequelae, extensively explain autism spectrum disorder symptomatology. Brain Sciences, 9(6).

https://doi.org/10.3390/brainsci9060130

Wibisono, M. R., Findawati, Y., Mt, M., Informatika, T., Sidoarjo, U. M., Gelam, J. R., \& Sidoarjo, C. (n.d.). ( Tuna Grahita) Berbasis Android.

Yarsiah, D. D., \& Kasiyati. (2019). Efektivitas Plastisin Untuk Meningkatkan Keterampilan Motorik Halus Pada Anak Cerebral Palsy Di Slb Bina Bangsa. 7, 103-109.

Zhang, M., Liu, Z., Ma, H., \& Smith, D. M. (2020). Chronic Physical Activity for Attention Deficit Hyperactivity Disorder and/or Autism Spectrum Disorder in Children: A Meta-Analysis of Randomized Controlled Trials. Frontiers in Behavioral Neuroscience, 14(October), 1-10. https://doi.org/10.3389/fnbeh.2020.564886 